\title{
Kajian Waktu Etsa dan Penurunan Massa \\ PCB Double layer
}

\author{
B. Budiana*, Elin Aprilia*, Riki Ria*, Mchael Timanta Ginting* dan Budi Sugandi* \\ *Politeknik Negeri Batam \\ Jurusan Elektro \\ Jalan Ahmad Yani, Batam Centre, Batam 29461, Indonesia \\ E-mail: budiana@polibatam.ac.id
}

\begin{abstract}
Abstrak
Etsa $\mathrm{FeCl}_{3}$ merupakan proses menghilangkan bagian tertentu dari suatu material dengan menggunakan $\mathrm{FeCl}_{3}$ dengan konsentrasi minimum 28\%. Metode yang digunakan dengan larutan $\mathrm{FeCl}_{3}$ adalah metode reaksi kimia dengan bahan yang digunakan adalah PCB. Penelitian ini bertujuan untuk mengetahui pengaruh 3 variasi yang digunakan terhadap waktu etsa PCB dan penurunan massa PCB. Variasi karakterisasi yang digunakan yaitu plat PCB yang dietsa dengan menggunakan pemanasan dan stirer (PS), Plat PCB yang dietsa dengan menggunakan pemanasan tanpa menggunakan stirer (PTS) dan plat PCB yang dietsa tanpa menggunakan pemanasan dan stirer (TPTS). Setelah dilakukan proses etsa, plat PCB dikarakterisasi menggunakan Mikroskop Optik Motik SMZ168. Berdasarkan penelitian yang telah dilakukan, plat PS memiliki nilai kehilangan massa yang lebih tinggi jika dibandingkan dengan PTS dan TPTS. Waktu yang dibutuhkan untuk proses etsa PCB PS terjadi pada waktu 5 menit lebih cepat dibandingkan dengan PCB PTS yang berlangsung selama 10 menit dan PCB TPTS yang berlangsung selama 20 menit.
\end{abstract}

Kata kunci: Etsa, stirer, PS, TPS, TPTS

\begin{abstract}
$\mathrm{FeCl}_{3}$ Etching is the process of removing certain parts of a material using $\mathrm{FeCl}_{3}$ with a minimum concentration of $28 \%$. The method used with $\mathrm{FeCl}_{3}$ solution is a chemical reaction method and material etched is $\mathrm{PCB}$. This study aims to determine the effect of 3 variations used on etching time and PCB mass reduction. Characterization variation used is PCB plate etched using heating and stirrer (PS), PCB plate etched using heating without using stirrer (PTS) and PCB plate etched without using heating and stirrer (TPTS). After the etching process, the PCB plate is characterized using Optik Motik SMZ168. Based on the research, the mass reduction value of PS is highest for all variations and the etching time of PS occurs at 5 minutes is the fastest than the PTS (10 minutes) and TPTS (20 minutes).
\end{abstract}

Keywords: Etching, stirer, PS, TPS, TPTS

\section{Pendahuluan}

Teknologi Rekayasa material terdiri dari tahap persiapan, karakterisasi maupun aplikasi[1]. Tahap persiapan terdiri dari tahap sintesis atau tahap pemilihan material yang akan digunakan sebelum proses karakterisasi dilakukan. Tahap sintesis terdiri dari tahapan awalan material yang dipersiapkan dengan tujuan tertentu sedangkan tahap pemilihan material merupakan tahapan awal dari proses rekayasa material yang mempertimbangkan berbagai aspek sifat kimia, fisika serta ketersediaan yang ada di alam. Tahap karakterisasi terdiri dari serangkaian pengolahan hasil dari tahap sintesis. Tahap ini juga dapat mengawali sebuah pengambilan keputusan dari suatu material untuk digunakan sebagai material yang akan digunakan pada tahap aplikasi. Tahap aplikasi merupakan tahapan akhir dari sebuah serangkaian proses material. Tahapan ini melibatkan tahapan pengambilan keputusan dari suatu material dengan sifat fisika dan kimianya yang terbentuk setelah proses karakterisasi diperoleh [1].

Salah satu contoh tahapan pemilihan material adalah pemilihan bahan kimia atau larutan kimia yang akan digunakan pada manufaktur PCB. Manufaktur PCB terdiri dari serangkaian proses yang melibatkan proses fisika dan kimia. Salah satu proses yang terjadi dalam manufaktur PCB adalah Etsa. Etsa adalah proses menghilangkan bagian tertentu dari suatu material dengan menggunakan larutan kimia. Larutan 
kimia yang digunakan merupakan asam kuat yang dapat merusak permukaan bahan [2]. Beberapa larutan kimia yang sering digunakan dalam proses etsa terdiri dari ferric chloride $\left(\mathrm{FeCl}_{3}\right)$, ammonium persulfat, asam chromic, cupric chloride $\left(\mathrm{CuCl}_{2}\right)$, dan alkaline amonia $[2,3,4,6]$.

$\mathrm{FeCl}_{3}$ merupakan bahan etsa yang sering digunakan dalam proses pencetakan dan proses etsa PCB di industri. Keunggulan $\mathrm{FeCl}_{3}$ jika dibandingkan dengan larutan kimia lain yaitu memiliki laju etsa yang tinggi dan kapasitas pelarutan tembaga yang tinggi $[3,4]$.

Proses etsa merupakan proses yang sangat menarik untuk dikaji baik dari laju etsa yang berlangsung pada material, selektivitasnya, kualitas permukaan yang terbentuk, keseragaman arah etsa maupun reproduktivitasnya [2]. Mekanisme terjadinya proses etsa dapat dikelompokan menjadi 3 tahapan utama yaitu tahapan awalan, tahap terbentuk reaksi kimia dan tahap perpindahan materi etsa. Tahap awalan merupakan tahap awal pergerakan larutan etsa ke permukaan bahan yang akan dietsa. Tahap yang kedua adalah tahap terbentuk reaksi kimia antara larutan etsa dengan permukaan yang dietsa. Tahap yang terakhir adalah tahapan ketika terjadinya pergerakan produk reaksi yang terbentuk antara larutan etsa dengan permukaan PCB yang dietsa [2].

Proses etsa dapat diklasifikasikan menjadi 3 berdasarkan metode yang digunakannya yaitu metode etsa dengan reaksi kimia, metode etsa dengan elektrokimia atau chemical milling atau dengan metode etsa secara mekanik [8].

Penelitian ini berfokus pada larutan $\mathrm{FeCl}_{3}$ sebagai larutan etsa dengan konsentrasi yang digunakan adalah 28\%. Pemilihan konsentrasi ini berdasarkan pada rujukan minimum yang digunakan oleh peneliti sebelumnya [7,8]. Metode yang akan digunakan pada penelitian ini adalah metode etsa dengan reaksi kimia. Variasi perlakuan yang diberikan terdiri dari 3 variasi yaitu pemanasan dengan stirer, pemanasan dan tanpa pemanasan.

\section{Metode Penelitian}

\section{a. Persiapan PCB double layer}

PCB dengan ukuran $1 \mathrm{~cm}$ x $1 \mathrm{~cm}$ dibersihkan dengan menggunakan alkohol. Tujuan penggunaan alkohol pada PCB adalah untuk membersihkan permukaan PCB dari debu dan kotoran sehingga tidak mengganggu proses etsa berlangsung. Setelah PCB dibersihkan maka PCB dikeringkan pada suhu $30^{\circ} \mathrm{C}$ selama 15 menit.

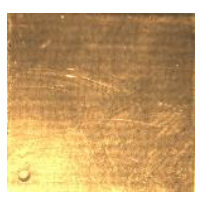

Gambar 1. Plat PCB yang telah dibersihkan dengan menggunakan alkohol $70 \%$.

\section{b. Pembuatan larutan $\mathrm{FeCl}_{3}$}

Langkah yang dilakukan untuk mendapatkan persentase $28 \% \mathrm{FeCl}_{3}$ adalah sebagai berikut:

a. $\mathrm{FeCl}_{3}$ ditimbang dengan massa 140 gram dan dimasukan kedalam beaker glass ukuran $500 \mathrm{ml}$. Selama proses pelarutan terjadi, bak berisi air dingin ditempatkan dibawah beaker glass untuk menghilangkan panas yang terbentuk selama proses kimia terjadi (reaksi eksotermis).

b. DI water ditambahkan sebanyak $300 \mathrm{ml}$ kedalam $\mathrm{FeCl}_{3}$ yang terdapat pada beaker glass sedikit demi sedikit.

c. Setelah penambahan DI water, $70 \mathrm{ml} \mathrm{HCl}$ ditambahkan dengan persentase $36 \%$ sehingga konsentrasi akhir $\mathrm{HCl}$ menjadi 5\% dan Air ditambahkan sampai mencapai volume total 500 $\mathrm{ml}$.

d. Larutan yang terbentuk distirer selama 30 menit sehingga larutan bersifat homogen.

\section{c. Pemasangan PCB double layer pada larutan $\mathrm{FeCl}_{3}$}

Plat PCB double layer diikat dengan menggunakan tali berbahan polimer pada sebuah batang kayu. Jarak antar plat PCB satu terhadap PCB lainnya adalah 0,5 $\mathrm{cm}$ dengan ketinggian tali untuk masing plat sama terhadap larutan. Temperatur yang digunakan pada plat plat $\mathrm{PCB}$ yang dipanaskan adalah $50^{\circ} \mathrm{C}$ dan kecepatan stirer yang digunakan adalah $5 \mathrm{rpm}$.

Penamaan Variasi yang diberikan adalah sebagai berikut:

a. Plat PCB yang dietsa dengan menggunakan pemanasan dan stirer dinamakan PS

b. Plat PCB yang dietsa dengan pemanasan tanpa menggunakan stirer dinamakan TPS

c. Plat PCB yang dietsa tanpa menggunakan pemanasan dan stirer TPTS

Berikut adalah gambar dari PS, TPS, TPTS

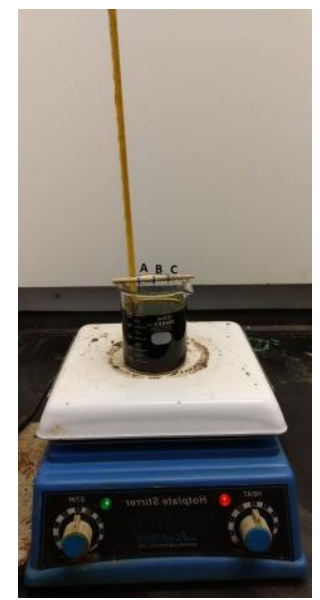

Gambar 2. PCB PS yang diikat pada batang dan akan dietsa pada larutan $\mathrm{FeCl}_{3}$ (Keterangan A: Plat A, B: Plat B, C: Plat C) 


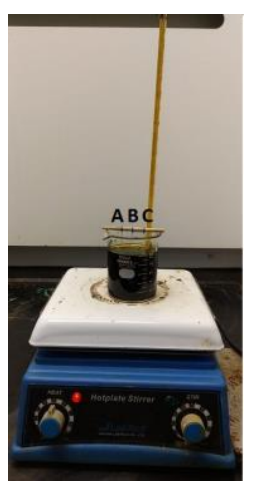

Gambar 3. PTS yang diikat pada batang dan akan dietsa pada larutan $\mathrm{FeCl}_{3}$ (Keterangan A: Plat A, B: Plat B, C: Plat C)

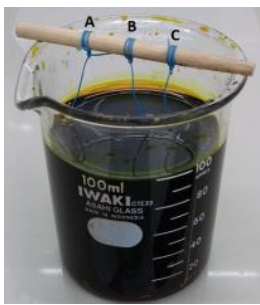

Gambar 4. PCB TPTS yang diikat pada batang dan akan dietsa pada larutan $\mathrm{FeCl}_{3}$ (Keterangan A: Plat A, B: Plat B, C: Plat C)

\section{d. Pengambilan Data Massa untuk masing-masing Plat A, B dan C}

Massa untuk masing-masing plat ditimbang baik sebelum dilakukan etsa maupun setelah dilakukan etsa. Plat yang telah ditimbang kemudian dikarakterisasi menggunakan mikroskop optik untuk dilihat permukaan atas dan bawahnya. Waktu pengambilan data adalah 5 menit, 10 menit, 15 menit dan 20 menit.

\section{Hasil dan Pembahasan}

Etsa dilakukan dengan rentang 5 menit. Pengambilan data hanya dilakukan sampai menit ke 20. Pengambilan data ini merujuk pada tingkat efisiensi dari etsa yang terjadi pada plat PCB. Jika etsa pada PCB lebih dari 20 menit dikhawatirkan akan menimbulkan biaya produksi yang lebih tinggi selama proses pabrikasi PCB. Berikut adalah hasil dari PCB yang telah dietsa pada waktu tertentu:

\section{a. Pemanasan dengan Stirer (PS)}

Variasi pertama yang diberikan adalah Pemanasan dengan Stirer. Pemanasan yang diberikan pada plat $\mathrm{PCB}$ double layer ini adalah $55^{\circ} \mathrm{C}$ dengan kecepatan putaran stirer $5 \mathrm{rpm}$. Pemanasan yang diberikan dijaga konstan dan dibaca melalui termometer yang dimasukan kedalam larutan $\mathrm{FeCl}_{3}$, kecepatan putaran stirer dijaga tetap dengan kecepatan $5 \mathrm{rpm}$.

Hasil yang diperoleh dengan pemberian perlakuan tersebut disajikan pada tabel 1 .
Tabel 1. Data Gambar PCB double layar PS sebelum dan sesudah dilakukan etsa

\begin{tabular}{|c|c|c|c|}
\hline $\begin{array}{c}\text { Waktu } \\
\text { (menit) }\end{array}$ & Plat A & Plat B & Plat C \\
\hline $\begin{array}{c}\text { Sebelum } \\
\text { Etsa }\end{array}$ & & & \\
\hline \multirow{5}{*}{5} & & & \\
& & & \\
\cline { 2 - 4 } & \multicolumn{3}{|c|}{ Permukaan atas } \\
\cline { 2 - 4 } & \multicolumn{3}{|c|}{ Permukaan bawah } \\
\hline
\end{tabular}

Berdasarkan tabel 1 dapat dilihat bahwa plat PCB double layer mengalami pengelupasan permukaan setelah 5 menit. Hal ini menunjukan telah terjadinya reaksi kimia antara larutan $\mathrm{FeCl}_{3}$ dengan permukaan bahan yang dietsa. Adapun reaksi kimia yang terjadi adalah sebagai berikut:

$$
\begin{array}{ll}
\mathrm{Cu}+\mathrm{FeCl}_{3} \longrightarrow \mathrm{FeCl}_{2}+\mathrm{CuCl} \\
\mathrm{FeCl}_{3}+\mathrm{CuCl} \longrightarrow \mathrm{FeCl}_{2}+\mathrm{CuCl}_{2} \\
\mathrm{CuCl}_{2}+\mathrm{Cu} \longrightarrow 2 \mathrm{CuCl}
\end{array}
$$

Untuk mendapatkan nilai kuanitatif maka dilakukan perhitungan massa dari plat PCB sebelum dimasukan kedalam larutan etsa dan sesudah dimasukan kedalam larutan etsa.

Tabel 2. Data Massa PS sebelum dan sesudah proses etsa

\begin{tabular}{|l|c|c|c|}
\hline $\begin{array}{c}\text { Massa } \\
\text { Ke- }\end{array}$ & $\begin{array}{c}\text { Plat A } \\
(\text { Gram })\end{array}$ & $\begin{array}{c}\text { Plat B } \\
(\text { Gram })\end{array}$ & $\begin{array}{c}\text { Plat C } \\
(\text { Gram })\end{array}$ \\
\hline M0 & 0,3400 & 0,3500 & 0,3200 \\
\hline M5 & 0,2165 & 0,2206 & 0,2235 \\
\hline
\end{tabular}

\section{Keterangan}

M0 : Massa PCB sebelum terjadinya etsa

M5 : Selisih Massa PCB setelah terjadinya etsa dan sebelum terjadinya etsa dengan waktu 5 menit

Setelah dilakukan perhitungan massa maka dilakukan perhitungan kehilangan massa dengan rumus sebagai berikut:

$$
\% \mathrm{KM}=\frac{m a-m b}{m a} \times 100 \%
$$

Catatan:

$\mathrm{ma}=$ massa sebelum dimasukan kedalam larutan etsa $\mathrm{mb}=$ massa setelah dimasukan kedalam larutan etsa

dengan menggunakan persamaan 4 maka diperoleh hasil seperti yang ditunjukan pada tabel 3 . 
Tabel 3. Data kehilangan Massa PCB PS

\begin{tabular}{|l|r|r|r|c|}
\hline \multirow{2}{*}{$\begin{array}{c}\text { Selisih } \\
\text { Massa }\end{array}$} & \multicolumn{3}{|c|}{$\begin{array}{c}\text { Persesentase Kehilangan } \\
\text { Massa (\%) }\end{array}$} & \multirow{2}{*}{$\begin{array}{c}\text { Rata-Rata } \\
(\%)\end{array}$} \\
\cline { 2 - 4 } & Plat A & Plat B & Plat C & \\
\hline M05 & 36,31 & 36,97 & 30,16 & 34,48 \\
\hline
\end{tabular}

\section{Keterangan}

M05 : Massa PCB setelah terjadinya etsa dengan waktu 5 menit

\section{b. Pemanasan tanpa stirer (PTS)}

Berikut adalah gambar dari plat PCB sebelum dilakukan etsa dan setelah dilakukan etsa untuk plat PTS

Tabel 4. Data Gambar PCB double layar TPS sebelum dan sesudah dilakukan etsa

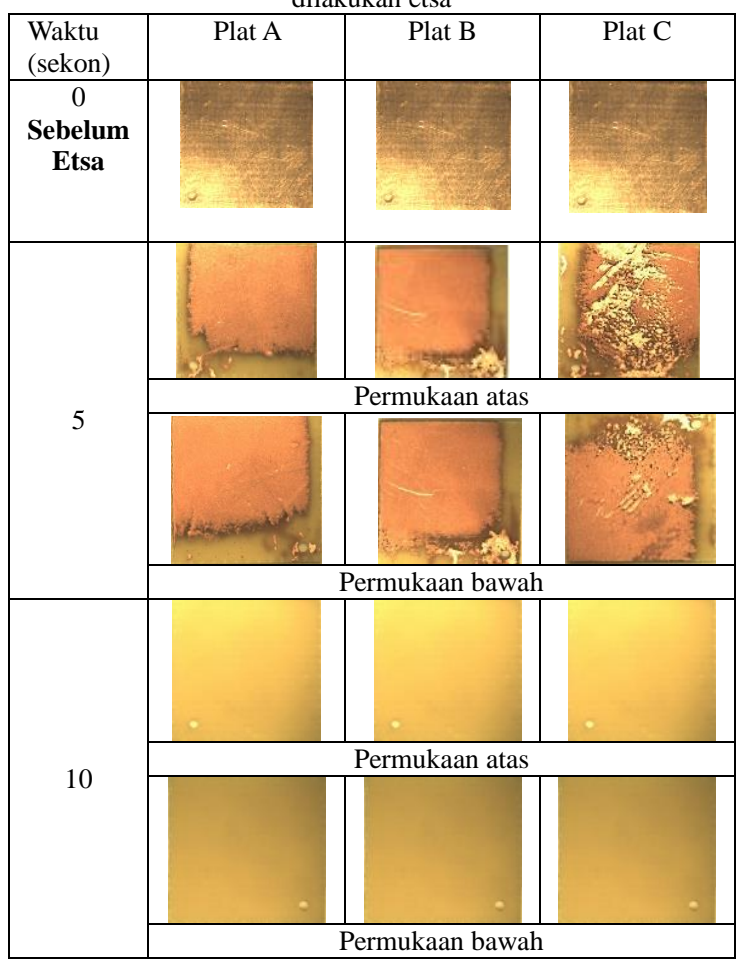

Berdasarkan gambar pada tabel 4 dapat dilihat bahwa ketika etsa berlangsung (setelah 5 menit dilakukan proses etsa) terjadi pengelupasan permukaan logam. Pengelupasan dimulai dari ujung sisi plat PCB kemudian bergerak sedikit demi sedikit ke bagian tengah. Permukaan atas dan permukaan bawah dari plat PCB terlihat sama pola etsa yang terjadi.

Tabel 5. Data Massa PCB double layer PTS

\begin{tabular}{|l|c|c|c|}
\hline $\begin{array}{c}\text { Massa } \\
\text { Ke- }\end{array}$ & $\begin{array}{c}\text { Plat A } \\
(\text { Gram })\end{array}$ & $\begin{array}{c}\text { Plat B } \\
\text { (Gram) }\end{array}$ & $\begin{array}{c}\text { Plat C } \\
\text { (Gram })\end{array}$ \\
\hline M0 & 0,3500 & 0,3500 & 0,3500 \\
\hline M5 & 0,2457 & 0,2514 & 0,2433 \\
\hline M10 & 0,2333 & 0,2268 & 0,2199 \\
\hline
\end{tabular}

\section{Keterangan}

M0 : Massa PCB sebelum terjadinya etsa

M5 : Massa PCB setelah terjadinya etsa dengan waktu 5 menit

M10 :Massa PCB setelah terjadinya etsa dengan waktu etsa 10 menit

Adapun kehilangan massa dari plat PCB dengan pemanasan tanpa menggunakan stirer disajikan pada tabel 6.

Tabel 6. Data Kehilangan Massa PCB double layer TPS

\begin{tabular}{|l|c|c|c|r|}
\hline \multirow{2}{*}{$\begin{array}{l}\text { Selisih } \\
\text { Massa }\end{array}$} & \multicolumn{3}{|c|}{ Persesentase Kehilangan Massa } & \multirow{2}{*}{$\begin{array}{c}\text { Rata-Rata } \\
(\%)\end{array}$} \\
\cline { 2 - 4 } & Plat A & Plat B & Plat C & \\
\hline M05 & 29,8131 & 28,1800 & 30,5000 & 29,50 \\
\hline M010 & 33,3491 & 35,2046 & 37,1766 & 35,24 \\
\hline
\end{tabular}

\section{Keterangan:}

M05 : Selisih Massa PCB setelah terjadinya etsa dengan sebelum terjadinya etsa, rentang waktu 5 menit

M010 :Selisih Massa PCB setelah terjadinya etsa dengan sebelum terjadinya etsa, rentang waktu 10 menit

\section{c. Tanpa Pemanasan dan Tanpa stirer (TPTS)}

Variasi yang ketiga adalah TPTS. Berikut hasilnya disajikan pada tabel 7 .

Tabel 7. Data Gambar PCB double layer sebelum dan sesudah dilakukan etsa

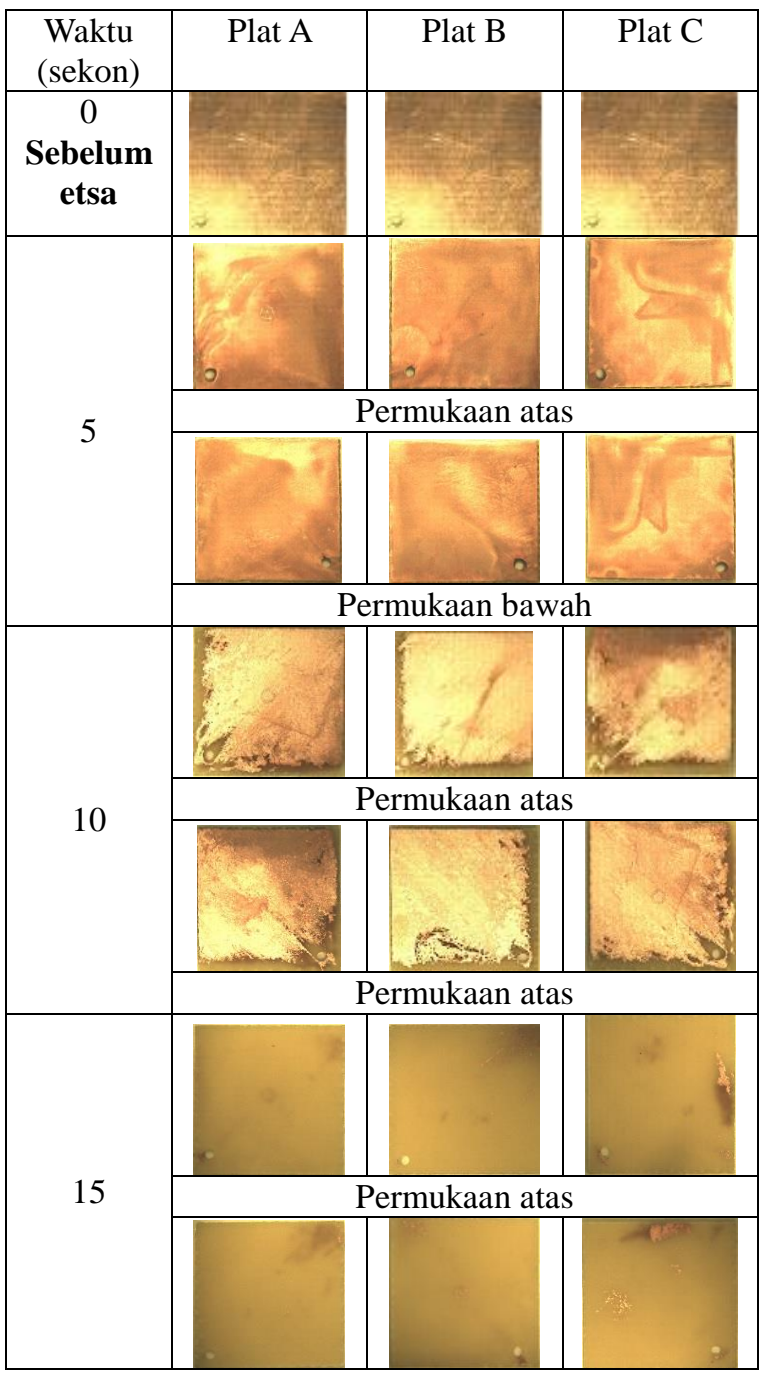

89 | Jurnal Integrasi | Vol.10 No.2, October 2018, 86-91 | e-ISSN: 2548-9828 


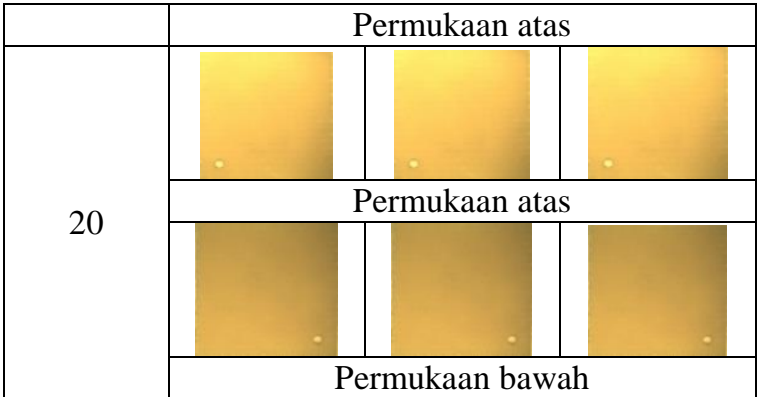

Berdasarkan tabel 6 dapat dilihat bahwa nilai kehilangan massa untuk proses etsa setelah 5 menit dan setelah 10 menit berbeda-beda untuk setiap plat. Salah satu faktor yang memungkinkan terjadinya perbedaan tersebut adalah distribusi temperatur larutan yang tidak seragam. Jika distribusi temperatur pada larutan tidak seragam akan mengakibatkan reaksi kimia yang terjadi antara larutan etsa dengan logam yang melapisi PCB akan berbeda-beda sehingga migrasi produk hasil dari reaksi kimia yang terjadi berbeda juga

Berdasarkan tabel 7 dapat dilihat bahwa permukaan PCB mulai terjadi pengelupasan permukaan akibat dari rekasi kimia yang terjadi pada rentang waktu 5 menit. Permukaan PCB mulai berbeda antara sebelum dietsa dan sesudah dietsa. Hal ini dapat dilihat pada waktu etsa selama 5 menit, gambar permukaan atas dan permukaan bawah mulai menunjukan adanya perbedaan warna permukaan antara bagian pinggir plat dan bagain tengah pelat. Proses yang terjadi pada waktu 5 menit ini disebut sebagai proses awalan terbentuknya reaksi kimia antara larutan $\mathrm{FeCl}_{3}$ dengan lapisan logam.

Waktu etsa dilanjutkan selama 10 menit dengan hasil etsa menunjukan terjadinya pegelupasan logam dibagian pinggir dari plat PCB. Hal ini ditunjukan dengan warna kuning yang terbentuk dipinggir plat PCB. Permukaan plat PCB bagian atas dengan permukaan bawah terlihat memiliki pola etsa yang sama. Hal ini menunjukan reaksi kimia yang terjadi bersifat isotropik. Proses etsa dilanjutkan kembali selama 15 menit.

Hasil yang diperoleh berdasarkan tabel 7 menunjukan bahwa plat PCB hampir seluruhnya berubah warna menjadi warna kuning. Terdapat beberap titik yang masih belum mengalami pengelupasan. Sehingga proses etsa perlu dilanjutkan kembali. Proses etsa dilakukan kembali selama 5 menit sehingga total waktu etsa berjumlah 20 menit dan hasil yang dipeoleh adalah lapisan permukaan bagian atas PCB lepas.

Nilai massa dari plat PCB dihitung baik sebelum dan sesudah terjadinya etsa. Hasil yang diperoleh disajikan pada tabel 8 .
Tabel 8. Data Massa PCB double layar dengan konsentras $28 \%$ $\mathrm{FeCl}_{3}$ tanpa pemanasan

\begin{tabular}{|l|c|c|c|}
\hline $\begin{array}{c}\text { Massa } \\
\text { Ke- }\end{array}$ & $\begin{array}{c}\text { Plat A } \\
(\text { Gram })\end{array}$ & $\begin{array}{c}\text { Plat B } \\
(\text { Gram })\end{array}$ & $\begin{array}{c}\text { Plat C } \\
(\text { Gram })\end{array}$ \\
\hline M0 & 0,3500 & 0,3500 & 0,3500 \\
\hline M5 & 0,3024 & 0,3024 & 0,3119 \\
\hline M10 & 0,2440 & 0,2535 & 0,2568 \\
\hline M15 & 0,2186 & 0,2251 & 0,2244 \\
\hline M20 & 0,2185 & 0,2248 & 0,2240 \\
\hline
\end{tabular}

\section{Keterangan}

M0 : Massa PCB sebelum terjadinya etsa

M05 : Massa PCB setelah terjadinya etsa dengan waktu 5 menit

M10 :Massa PCB setelah terjadinya etsa dengan waktu etsa 10 menit

M15 : Massa PCB setelah terjadinya etsa dengan waktu 15 menit

M20 :Massa PCB setelah terjadinya etsa dengan waktu etsa 20 menit

Nilai kehilangan massa untuk plat PCB tanpa menggunakan pemanasan disajikan pada tabel 9.

Tabel 9. Data Massa PCB double layer TPTS

\begin{tabular}{|l|c|c|c|r|}
\hline \multirow{2}{*}{$\begin{array}{l}\text { Selisih } \\
\text { Massa }\end{array}$} & \multicolumn{3}{|c|}{$\begin{array}{c}\text { Persesentase Kehilangan Massa } \\
(\%)\end{array}$} & \multirow{2}{*}{$\begin{array}{c}\text { Rata-Rata } \\
(\%)\end{array}$} \\
\cline { 2 - 4 } & Plat A & Plat B & Plat C & \\
\hline M05 & 13,5900 & 13,5900 & 10,8900 & 12,69 \\
\hline M010 & 30,2800 & 27,5600 & 26,6300 & 28,16 \\
\hline M015 & 37,5400 & 35,7000 & 35,8800 & 36,37 \\
\hline M020 & 37,5700 & 35,7600 & 36,0000 & 36,44 \\
\hline
\end{tabular}

Keterangan:

M05 : Selisih Massa PCB setelah terjadinya etsa dengan sebelum terjadinya etsa, rentang waktu yang digunakan adalah 5 menit

M010 :Selisih Massa PCB setelah terjadinya etsa dengan sebelum terjadinya etsa, rentang waktu yang digunakan adalah 10 menit

M015 :Selisih Massa PCB setelah terjadinya etsa dengan sebelum terjadinya etsa, rentang waktu yang digunakan adalah 15 menit

M020 :Selisih Massa PCB setelah terjadinya etsa dengan sebelum terjadinya etsa, rentang waktu yang digunakan adalah 20 menit

Berdasrkan data kehilangan massa yang terdapat pada tabel 3, 6 dan 9 untuk semua perlakuan maka dibandingkan semua parameter yang bekerja. Hasil yang diperoleh disajikan pada gambar 5.

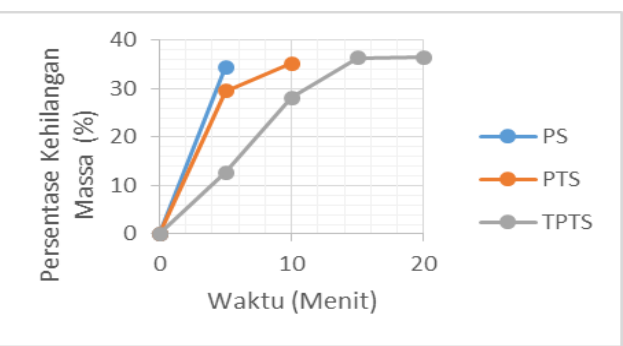

Gambar 5. Grafik Hubungan antara waktu dengan presentase kehilangan massa untuk PS, PTS, TPTS 
Berdasarkan gambar 5 terlihat bahwa persentase kehilangan massa PS lebih tinggi jika dibandingkan dengan PTS dan TPTS. Hal ini terjadi akibat dari perbedaan reaksi kimia yang berlangsung. Pemanasan dengan menggunakan stirer memiliki tingkat migrasi produk reaksi yang lebih besar bila dibandingkan dengan pemanasan tanpa menggunakan stirer dan tanpa pemanasan. Pemanasan memungkinkan reaksi kimia yang terjadi berlangsung cepat karena energi kinetik yang terjadi lebih besar bila dilakukan tanpa menggunakan pemanasan. Penggunaan stirer memungkinkan terjadinya penambahan energi dari luar sehingga rekasi kimia yang terjadi juga berlangsung cepat jika dibandingkan dengan parameter lainnya.

\section{Kesimpulan}

Berdasarkan penelitian yang telah dilakukan diperoleh kesimpulan sebagai berikut:

a. PCB double layer PS memiliki persentase kehilangan massa yang lebih tinggi jika dibandingkan dengan PTS dan TPTS.

b. Waktu yang dibutuhkan untuk proses etsa plat PCB PS terjadi pada waktu 5 menit lebih cepat dibandingkan dengan TPS yang berlangsung selama 10 menit dan TPTS yang berlangsung selama 20 menit.

Penelitian selanjutnya diharapkan dapat mengkaji perubahan nilai konsentrasi terhadap laju etsa dan dapat menganalisa gambar dari PCB yang telah dietsa.

\section{Terima Kasih}

Ucapan terima kasih kami haturkan kepada Kementerian Riset, Teknologi dan Pendidikan tinggi dan juga kepada Politeknik Negeri Batam melalui Unit P2M yang telah memberikan dukungan finansialnya selama kegiatan penelitian berlangsung serta kami haturkan terima kasih kepada seluruh staf program Prodi Elektronika Manufaktur dibawah Jurusan Teknik Elektronika atas kerja sama dan fasilitas yang diberikan selama melakukan penelitian

\section{Daftar Pustaka}

[1] M. Franulovic, R. Basan, I. Prebil, A. Trajkovski, T. Maronic, "Materials Characterization - From Metal to soft tissues", Materials Discovery 7(7), pp 1-7. 2017.

[2] D.H Patil, S.B Thorat, R.A Khake, S. Mudigonda, "Comparative Study of $\mathrm{FeCl}_{3}$ and $\mathrm{CuCl}_{2}$ on Geometrical Features Using Photochemical Machining of Monel 400". Procedia CIRP 68, pp 144-149. 2018
[3] H.C Jeong, D. W Kim, G. M Choi, D.J Kim. "The Effect of spray characteristic on the etching of invar alloy with $\mathrm{FeCl}_{3}$ solutions". International Journal of Precision Engineering and Manufacturing. 2009

[4] O. Cakır, "Chemical etching of aluminium", Journal of Materials Processing Technology 199(1), pp 337-340. 2008.

[5] O. Cakır, "Review of etchant of Copper and its Alloys in Wet Etching Processes", IOSR Journal of Engineering 364-366. Pp 460-465. 2008

[6] O. Cakır, "Copper etching with cupric chloride and regeneration of waste etchant", Journal of Materials Processing Technology 175(1-3), pp 63-68. 2006.

[7] R.S Khandpur, Printed Circuit Boards Design, Fabrication, and Assembly, Mc Graw Hill Electronic Enggineering. 2006.

[8] Cylde F. Coombs, Jr, Printed Circuit Handbook Sixth Edition. Mc Graw Hill Electronic Enggineering. 2008. 